\title{
Understanding the Influence of CEO Tenure and CEO Reputation on Corporate Reputation: An Exploratory Study in Italy
}

\author{
Francesca Conte ${ }^{1}$ \\ ${ }^{1}$ Department of Political, Social and Communication Sciences. University of Salerno, Italy \\ Correspondence: Francesca Conte, Department of Political, Social and Communication Sciences. University \\ of Salerno, Italy. E-mail: fconte@unisa.it \\ Received: December 28, 2017 \\ Accepted: January 23, 2018 \\ Online Published: February 25, 2018 \\ doi:10.5539/ijbm.v13n3p54 \\ URL: https://doi.org/10.5539/ijbm.v13n3p54
}

\begin{abstract}
The study aims at investigating the main activities of corporate reputation in which CEOs are actively engaged, focusing also on the influence of CEOs tenure on their commitment in reputation management. Moreover, the paper analyzes the CEO's view on the relation between CEO reputation and company's reputation. Through a structured questionnaire, a web survey has been carried out addressing CEOs of large companies located in Italy and included in the report of Mediobanca. Findings highlight a relevant CEO commitment in corporate reputation management, above all in leadership, performance and workplace activities. Long-tenured CEOs tend to be more involved in managing firm's reputation, than short-tenured CEOs. The study also shows CEOs are aware that their reputation are increasingly intertwined with the corporate reputation. The paper supports the strategic leadership perspective, contributing to the ongoing debate on CEO reputation. The influence of CEOs' good name on company's reputation stimulates them, and communication managers, to create an effective CEOs' brand. The paper is the first study that provides empirical evidence on the increasing importance of CEO's role in Italian large companies, and it can be viewed as a starting point for future cross-country comparison.
\end{abstract}

Keywords: CEO tenure, CEO reputation, corporate reputation, strategic leadership perspective

\section{Introduction}

A growing body of research argues that company's reputation is an increasingly critical corporate asset directly linked to competitive success, because of its strategic value for the organization (Weigelt \& Camerer, 1988; Gray \& Balmer, 1998; Roberts \& Dowling, 2002). Some studies emphasize, in fact, the concept of "reputation economy", demonstrating the centrality of reputation in corporate business (Carreras, E., Alloza, \& Carreras, A., 2013). "Reputation does not occur by chance, it relates to leadership, management, organizational operations [...] and relationships with stakeholders" (Watson, 2007, p. 372). Managing reputation is crucial to obtain and maintain the corporate legitimacy by receiving support from public and creating trust relations (Gardberg, 2017).

In its role of setting the strategic direction of a firm, the top management has the direct responsibility for achieving the company's reputation objectives as it acts as the information-processing center of an organization in its relationships with stakeholders (Carter \& Greer, 2013). A grand deal of strategic leadership research points out, indeed, that the dominant coalition has a critical role in determining strategic competitiveness, strongly influencing firm outcomes (Hambrick \& Mason, 1984; Hambrick, 2007).

Several authors in the academic and business communities have considered the Chief Executive Officer (CEO) as the main corporate responsible in reputation management (Kitchen \& Laurence 2003; Murray \& White, 2005; van der Jagt, 2005; Gaines-Ross, 2008). Personifying the corporate culture, CEO became the "face and the voice of the firm", appearing as the human force behind the company's actions and outcomes (Bates, 2011; Love, Lim \& Bednar, 2017).

Recent studies indicate that a positive reputation of CEO can influence the perceptions of the organization among the stakeholders (Meng \& Berger, 2013; Weng \& Chen, 2017). In this perspective, the personal history and the experiences of CEO affect the sharing of corporate vision and the development of corporate reputation (Balmer, 2001). The top manager tends to become a celebrity CEO in many Western cultures, determining the companies' value and performance (Hamilton \& Zeckhauser, 2004; Malmendier \& Tate, 2005). Indeed, most reputable companies, according to studies by Fortune and the Financial Times, tend to have well-known CEOs, 
such as Steve Jobs, Bill Gates, Richard Branson, Jack Welch.

Although the impact of CEO role on company's outcomes is a well-documented concept in the literature (Rose \& Thomsen, 2004; Karuna, 2006; Weng \& Chen, 2017), little is known about the relation between CEO personal reputation and corporate reputation, and about the activities of reputation management in which CEOs play a key role. Moreover, most research regarding the influence of CEOs on corporate reputation has focused on the international context (van der Jagt, 2005). Conversely, there is a death of research in the Italian scenario (Kitchen \& Laurence, 2003), frequently characterized by the significant presence of family businesses and long-tenured CEOs (Corbetta, 2010; AIDAF, 2014). Finally, despite several studies aimed to analyze the impact of some proxies of CEO reputation (Kelly, Athanassiou, \& Crittenden, 2000; Song, 2006), the influence of CEO tenure on CEO commitment in reputation management has scarcely been explored in the leadership literature.

Thus, this study first aims to explore the activities of reputation management in which CEOs are more committed, investigating also the role of CEO tenure. Secondly, this paper intends to analyze CEO's self-perception on the link between CEO reputation and company's reputation.

The paper is organized as follows. The theoretical background provides the literature review on the CEO role in corporate reputation, CEO tenure and CEO reputation. It delineates the three research questions that are analyzed through an exploratory survey on the CEOs of large companies located in Italy, included in the report of Mediobanca. At last, the study provides the main research findings and discusses the implications of the results, thus providing insights for future research directions.

\section{Conceptual Background}

\subsection{CEO Role in Corporate Reputation Management}

CEOs are typically the most powerful members of the corporate elite, for their legitimate hierarchical status and their commitment to the organization (Jensen \& Zajac, 2004; Brown \& Sarma, 2007; Bates, 2011). CEOs tend to be committed particularly to the status quo, in order to ensure the correctness of current strategy and the persistence in specific leadership actions. In the organizational arena, CEO commitment to organization can be considered as a moral imperative that shows the strength of his/her identification with and involvement in an organization (Yucel, McMillan, \& Richard, 2014). CEO bears the final authority for setting and maintaining an organization's strategic course and achieving organizational performance.

Some research in business community and literature review shows that CEO can be considered the main responsible in corporate reputation management (Kitchen \& Laurence 2003; Murray \& White, 2005; van der Jagt, 2005; Gaines-Ross, 2008) (see tab. 1). CEO ensures the coordination of several organizational functions, deals with the development of the reputational risk strategy, monitoring in advance external threats and managing reputation in crisis conditions (Economist Intelligence Unit, 2005). CEO that holds the greatest responsibility in the management of reputation is defined in terms of the Chief Reputation Officer (Reputation Institute, 2012).

Some studies highlight that $\mathrm{CEO}$ takes more responsibility in the reputation management when companies have an advanced approach to reputation. Consequently, CEOs tend to analyze and measure the corporate reputation among all stakeholders, integrate reputational factors in the corporate vision and constitute a corporate board/department oriented to reputation management (Reputation Institute, 2012).

Table 1. CEO role in corporate reputation management

\begin{tabular}{ll}
\hline Authors & Contributions \\
\hline Kitchen \& Laurence, 2003 & CEO is the main responsible in corporate reputation management. \\
Economist Intelligence Unit, 2005 & The role of CEO is crucial in the management of reputational risk. \\
Murray \& White, 2005 & CEOs are the stewards of reputation for the period they are in office. \\
Jagt van der, 2005 & Communication and reputation are a crucial part of CEO leadership role. \\
Gainess Ross, 2008 & CEO plays a strategic role in the recovery of reputation after a crisis. \\
Reputation Institute, 2012 & CEO takes more responsibility in the reputation management when companies have \\
& an advanced approach to reputation. \\
\hline
\end{tabular}

Despite the growing focus on the pivotal role of CEOs in several dimensions of corporate reputation (Hambrick, Geletkanycz, \& Fredrickson, 1993; Alsop, 2004; Chang, Sudipto, \& Gilles, 2010; Love et al., 2017), there is a lack of studies that specifically analyze the commitment of CEOs in reputation management and provide a clear 
understanding of the main activities of reputation undertaken by CEOs. Thus, the first research question is: RQ1: What are the reputational activities in which CEOs are most committed?

\subsection{CEO Reputation}

CEOs tend to build over time a personal reputation that can be seen as the totality of enduring images that stakeholders form based on perceived CEO performance, his/her credibility, charisma, integrity and values (Ferris, Blass, Douglas, Kolodinsky, \& Treadway, 2003, Love et al., 2017). The literature review distinguishes two approaches related to CEO reputation: ability perspective and symbolic image perspective (Lee, 2006). The ability perspective emphasizes CEO's skills and competences in achieving company's goals (Daily \& Johnson, 1997; Baik, Farber, \& Lee, 2011). The symbolic image perspective refers to the power of the media coverage in creating celebrity CEOs (Hayward, Rindova, \& Pollock, 2004) and determining stakeholders' perceptions of CEO's quality (Love et al., 2017).

Identifying empirical proxies for CEO reputation is not a trivial task, especially because the assessment of this construct is realistically multidimensional, encompassing personal attributes that are typically difficult to quantify. Several studies have tried to define such proxies that are:

- media exposure: greater press coverage suggests that CEO is generally perceived by the media as a successful leader (Hayward \& Hambrick; 1997; Hamilton \& Zeckhauser, 2004; Park \& Berger, 2004);

- CEO award: the winners of awards become CEO superstars and highly reputed in the business community (Malmendier \& Tate 2005; Graffin, Wade, Porac, \& Mcnamee, 2008; Shi, Zhang, \& Hoskisson, 2017);

- CEO tenure: is the time (number of years) in which CEOs stay in their current position; long-tenured CEOs are expected to stay for more than six years (Weisbach, 1988; Song, 2006). A longer CEO tenure implies that the company's board has historically been inclined to retain this executive role (Shen \& Cannella, 2002; Milbourn, 2003; Bernstein, Buse, \& Bilimoria, 2016);

- insider or outsider: CEO outsider is more likely to introduce new business strategies and practices (Chung, Rogers, Lubatkin, \& Owers, 1987; Parrino, 1997; Zhang \& Rajagopalan, 2010);

- CEO age: it is a proxy for the market's uncertainty about the CEO's credibility (Yim, 2013; Serfling, 2014).

Among the different proxies of CEO reputation, CEO tenure plays a key role in affecting how CEOs manage company's strategy. In particular, several studies have examined the relationship between CEO tenure and company's performance (Wulf, Stubner, Miksche, \& Roleder, 2010; Huang, 2013), showing that long-tenured CEOs are likely to achieve some significant positive outcomes. Indeed, the longer the CEO's tenure, the more likely he or she will have been successful (Finkelstein, Hambrick, \& Cannella, 2009). Other researchers have explored the link between CEO tenure and entrepreneurial risk-taking behavior, pointing out that this CEO attribute has a significant influence (Boling, Pieper, \& Covin, 2016).

Long CEO tenure may also allow the CEO to build valuable relationships among organizational constituents (Kellermanns, Eddleston, Barnet, \& Pearson, 2008), as CEO tenure has a positive and linear association with the firm-employee relationship (Luo, Kanuri, \& Andrews, 2014). In fact, over the tenure, as CEOs gain greater familiarity with the organizational culture and resources, they develop a major commitment to organization and are more oriented to promote entrepreneurial initiatives.

The influence of CEO tenure on some dimensions related to corporate reputation management has been examined in the strategic literature. Several research has revealed, in fact, that CEO tenure is related to organizational outcomes including firm performance, strategic change, workplace, commitment to the status quo and risk taking (Brookman \& Thistle, 2009; Bernstein et al., 2016). However, the relation between CEO tenure and $\mathrm{CEO}$ commitment in corporate reputation management has remained largely unexplored. Rooted in the view of CEO tenure seasons (Hambrick \& Fukutomi, 1991), thus, the second research question is:

RQ2: Does CEO tenure affect CEO commitment in corporate reputation management?

\subsection{The Relation between CEO Reputation and Corporate Reputation}

Strategic-leadership theory seeks to understand the impact of top executive on organizations. In particular, in the view of upper echelon perspective (Hambrick \& Mason, 1984; Hambrick, 2007), CEO symbolically personifies the organization, contributing to shaping the firm's values and the major organizational outcomes (Pincus, Robert, Rayfield, \& Debonis, 1991; Vera \& Crossan, 2004; Love et al., 2017). Much research within this perspective has shown, in fact, that executive characteristics can impact a range of strategic choices and performance (Finkelstein et al., 2009). CEO is a "symbol of corporate identity" and his/her professional 
backgrounds, conducts, distinctive values and personalities have an influence on what stakeholders perceive, feel and think about the organization (Hatch \& Schultz, 1997; Melewar \& Karaosmanoglu, 2006; Lo \& Fu, 2016).

Therefore, the behavior and communications of CEOs are critical factors in corporate reputation building. Rindova, Williamson, Petkova, and Sever (2005) describe the "spillover effect" of a good reputation of CEO on the corporate reputation as the "transfer of a positive assessment by a social object to another" (p. 103).

Several studies highlight a close relationship between CEO reputation and corporate reputation (Gaines-Ross, 2000; 2003; Kitchen \& Laurence, 2003; Murray \& White, 2005), considering the influence of CEO role in stock-based performance measures (Milbourn, 2003; Karuna, 2006); corporate financial performance (Weng \& Chen, 2017), job retention (Lee, 2006); corporate governance internal (Karuna, 2009) and corporate reputation crisis (Sohn, Lariscy, \& Tinkham, 2009). Studies of CEO brand point out the importance of leadership in conveying a company's success and outcomes to the financial community and other stakeholders. This idea is supported by a large body of empirical research that confirms stakeholders see firms as a reflection of their leaders (Shane \& Cable, 2002; Burson-Marsteller, 2003; Gaines-Ross, 2003; Feldman, 2004). In several countries, CEOs were ranked as the third most important factor in influencing the corporate reputation (Kitchen \& Laurence, 2003). CEO reputation, in terms of impact on corporate reputation, has a greater importance in Italy, followed by Canada and the United States. The Italian organizational context is characterized by the presence of family firms that benefit from the CEO's close connections to stakeholders in local industrial districts (Handler, 1989; Naldi, Cennamo, Corbetta, \& Gomez - Mejia, 2013).

Starting from these insights and considering that the CEO's self-perception on their critical role in corporate reputation has received little theoretical and empirical attention, above all in Italy, the third research question is:

RQ3: Are CEOs aware of their influence in corporate reputation building?

\section{Method}

Given the difficulty in reaching selected respondents (CEOs of large companies), the paper exploits an exploratory approach through a structured questionnaire. In particular, the study adopts a "leader's self-report" (Jian, Shi, \& Dalisay, 2014), as it aims to investigate the CEOs' perceptions of their role in corporate reputation. The unit of analysis includes CEOs from companies located in Italy, reported in the "Principal Italian companies" of Mediobanca 2015. This report contains 1497 companies who achieved an annual turnover of at least 50 million euros. Company representatives from the branches of the group and business-to-business companies (665) were excluded from the analysis due to their limited corporate awareness of the general public. The same criteria were adopted by the main rankings of RepTrak Pulse of Reputation Institute. The resulting population consisted of 832 Italian companies. The study extracted a random sample of 349 companies ( $4 \%$ confidence interval) from the population.

Table 2. Respondent profiles (N. $=93)$

\begin{tabular}{llcrr}
\hline & & N. & \% \\
\hline Years of CEO tenure & Less than a year & Short-tenured CEOs & 8 & 8.6 \\
& From two to six years & (up to six years) & 35 & 37.6 \\
& From six to ten years & Long-tenured CEOs & 30 & 32.3 \\
& For more than ten years & (over six years) & 20 & 21.5 \\
& Tertiary/services & & 19 & 20.4 \\
& Food and beverage & 17 & 18.3 \\
& Textile & 13 & 14.0 \\
& Electronics & 10 & 10.8 \\
& Automobiles and Components & & 9.7 \\
& Bank/Insurance & 9 & 7.5 \\
& Telecommunication Services & 7 & 7.5 \\
& Transportation & 7 & 7.5 \\
& Chemical and Pharmaceuticals & & 7 & 4.3 \\
\hline
\end{tabular}

A total of 93 CEOs responded to the survey corresponding to a $26.7 \%$ response rate which is in line with other studies investigating similar populations, such as top managers (Waldman, Siegel, \& Javidan, 2006). CEOs were contacted mainly through personal email and social networks (LinkedIn, Facebook, Twitter) and thought the platform "Comunicazione Italiana". The companies in which the CEOs operated belong to different industries, 
especially "tertiary/services" (20.4\%), "food" (18.3\%) and "clothing" (14\%) sectors. Demographic results and backgrounds of respondents are detailed in Table 2.

Due to the absence of previous measurement instruments for the constructs to explore, the survey was generated by questions and items from the extant literature. The item generation approach is therefore deductive and ensures an adequate representation of the domains of interest within a construct (Jian et al., 2014). For RQ1, the study aims to investigate the main activities of reputation management in which CEOs are more committed, taking into account the dimensions of RepTrak Pulse (Reputation Institute, 2017): leadership, performance, governance, citizenship, workplace, innovation, product and service (7 items). For RQ2, the survey questions examine how the commitment of the CEOs in these activities varies considering the CEO tenure, that is one of the most important proxy of CEO reputation (Weisbach, 1988; Song, 2006). Lastly, for RQ3, the study analyzes the relation between $\mathrm{CEO}$ reputation and corporate reputation, relying on the scale adopted from Kitchen and Lawrence (2003).

\section{Results}

Findings highlight that the CEO is the most responsible in the management of corporate reputation. Referring to the seven dimensions of corporate reputation analyzed by Reputation Institute (Vision \& Leadership, Workplace, Innovation, Product \& Service, Performance, Citizenship, Governance), the activities in which CEOs appear to be actively committed are "spread inside and outside corporate vision (Leadership - mean value 1.17)", "monitor financial performance achievement (Performance - mean value 1.19)" and "motivate and encourage employees (Workplace - mean value 1.21)". Thus, CEOs show particular attention to the activities of institutional and internal relations (tab. 3). The activities that are mostly delegated to third parties relate to "Product and Service" ("ensure, through the control of product's quality, customer satisfaction" - mean value 1.94).

Table 3. Mean values ( $1=$ actively committed $-3=$ activities delegated to third parties), standard deviation and standard error mean for $\mathrm{CEO}$ commitment in cororate reputation management

\begin{tabular}{lcccc}
\hline CEO Activities for corporate reputation management & N. & Mean value & Std. deviation & SE mean \\
\hline Spread inside and outside corporate vision (Leadership) & 93 & 1.17 & .383 & .048 \\
Monitor financial performance achievement (Performance) & 93 & 1.19 & .396 & .050 \\
Motivate and encourage employees (Workplace) & 93 & 1.21 & .446 & .056 \\
Spread ethical conducts of the corporate governance (Governance) & 93 & 1.38 & .633 & .080 \\
Propose innovative solutions for products and services (Innovation) & 93 & 1.76 & .689 & .087 \\
Support and manage corporate sustainability initiatives (Citizenship) & 93 & 1.86 & .669 & .084 \\
Ensure customer satisfaction (Product and Service) & 93 & 1.94 & .801 & .101 \\
\hline
\end{tabular}

By accumulating scores assigned to these individual indicators, a composite index was developed, thus representing a more general dimension of the degree of CEO commitment in corporate reputation management.

The study used the procedure indicated in Babbie (2012), in order to ensure that all selected items had a logical validity and provided an adequate amount of variance. The points of this index thus correspond to two types of CEOs:

1) "pro-active CEOs" (Chief Reputation Officer - CRO) in corporate reputation management; in this category falls almost half of respondents (66.7\%);

2) "moderate CEOs", where the approach to reputation management is weighted and thoughtful (33.3\%);

The study shows that the CEO tenure is linked to CEO commitment in corporate reputation management (Tab. 4). In fact, long-tenured CEOs are more engaged in reputation management $(80.6 \%)$ and a significant positive correlation emerges $(p<0.05)$. 
Table 4. CEO commitment in corporate reputation management in relation to CEO tenure

\begin{tabular}{|c|c|c|c|c|}
\hline & & \multicolumn{2}{|c|}{ CEO commitment in corporate reputation } & \multirow[t]{2}{*}{ Total } \\
\hline & & Moderate CEOs & Pro-active CEOs (CRO) & \\
\hline \multicolumn{5}{|l|}{ CEO longevity } \\
\hline \multicolumn{2}{|c|}{ Short-tenured CEOs (up to 6 years) } & $46.9 \%$ & $53 i .1 \%$ & $100 \%$ \\
\hline \multicolumn{2}{|c|}{ Long-tenured CEOs (over 6 years) } & $19.4 \%$ & $80.6 \%$ & $100 \%$ \\
\hline \multirow[t]{3}{*}{ Total } & & $33.3 \%$ & $66.7 \%$ & $100 \%$ \\
\hline & & CEO longevity & $\begin{array}{l}\text { CEO commitment } \\
\text { corporate reputation }\end{array}$ & in \\
\hline & Pearson correlation & & 1 & .292 \\
\hline \multirow[t]{2}{*}{ CEO longevity } & Sig. (p) (2 tailed) & & & .020 \\
\hline & $\mathrm{N}$ & & 93 & 93 \\
\hline \multirow{3}{*}{$\begin{array}{l}\text { CEO commitment in } \\
\text { corporate reputation }\end{array}$} & Pearson correlation & & .292 & 1 \\
\hline & Sig. (p) (2 tailed) & & .020 & \\
\hline & $\mathrm{N}$ & & 93 & 93 \\
\hline
\end{tabular}

Figure. 1 shows the relation between CEO tenure and different reputation management activities in which CEOs are actively involved. Except for the activity related to the dissemination of corporate vision to stakeholders (Leadership \& Vision), that requires an active CEO commitment especially in the early years of CEO tenure, long-tenured CEOs are more engaged in the main activities of reputation management.

Thus, long-tenured CEOs seem to embody the role of Chief Reputation Officer. Over the years, in fact, they seem to become more aware of the importance of managing corporate reputation and intensify their role.

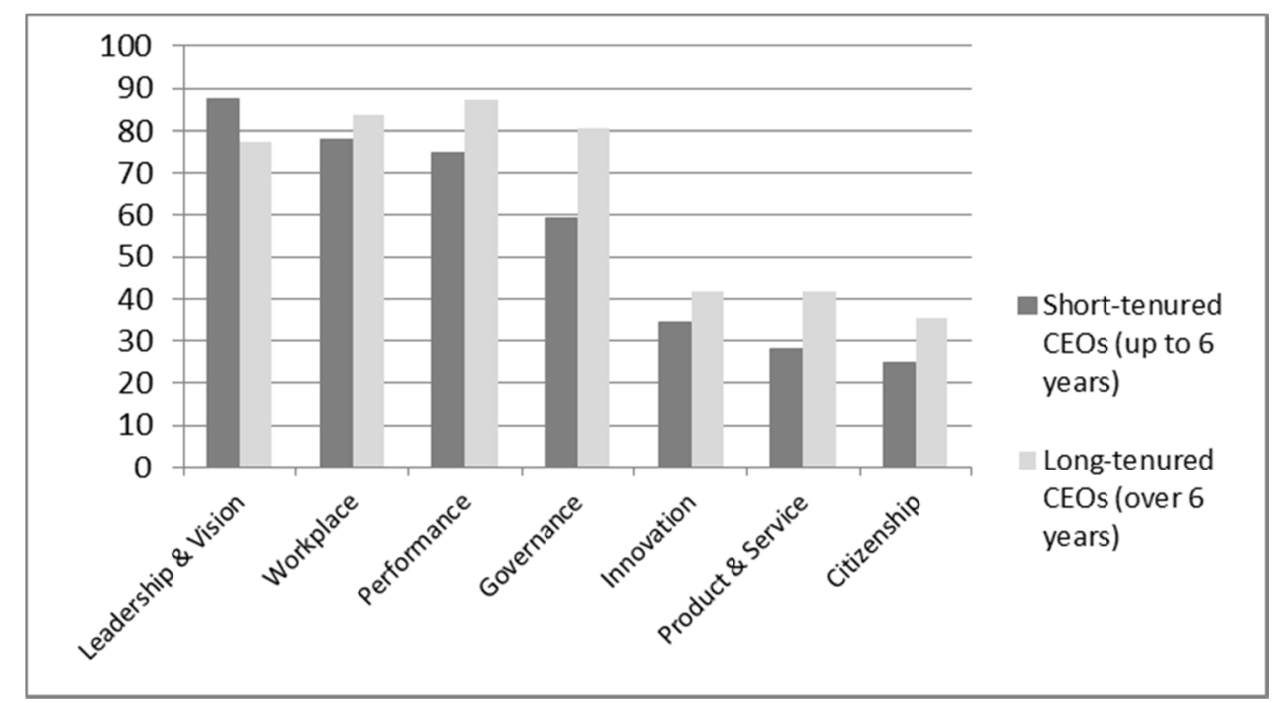

Figure 1. CEO commitment in corporate reputation management in relation to CEO tenure

Table 5 shows the results on the key aspects that, according to CEOs' view, may affect the corporate reputation (value between "1" - for nothing influential - and "10" - very influential). The survey points up CEOs consider the perception of customers and employees crucial in the corporate reputation building (mean of 8.7 and 7.8). The third factor is represented by the CEO reputation (mean of 7.8). 
Table 5. Factors that influence corporate reputation

\begin{tabular}{lrr}
\hline Factors influencing corporate reputation & Mean & DS \\
\hline Customers' perception & 8.7 & 2.4 \\
Employees' perception & 7.8 & 2.3 \\
CEO reputation & 7.8 & 2.1 \\
Shareholders' perception & 7.3 & 2.3 \\
Media coverage & 7.7 & 2.1 \\
The Internet & 6.8 & 2.2 \\
Regulators/governments' perception & 6.0 & 2.4 \\
\hline
\end{tabular}

Source: scale adapted from Kitchen and Lawrence, 2003.

Table 6 summarizes CEO self-perception on the relation between CEO reputation and corporate reputation. CEOs believe that CEO reputation has a significant incidence (over 50\%) on the corporate reputation building.

Table 6. Percentage that expresses how much company's reputation is based on CEO Reputation

\begin{tabular}{lr}
\hline Relation between CEO reputation and corporate reputation & $\mathbf{\%}$ \\
\hline $1 \%-24 \%$ & 10.2 \\
$25 \%-49 \%$ & 25.4 \\
$50 \%-74 \%$ & 35.6 \\
$75 \%-100 \%$ & 28.8 \\
Total & 100.0 \\
\hline
\end{tabular}

Source: scale adapted from Kitchen and Lawrence, 2003.

\section{Discussion}

The findings concerning RQ1 show a relevant CEO commitment in managing corporate reputation, above all in leadership, performance and workplace activities. This result supports several studies that highlight the role of CEO in shaping corporate vision and achieving organizational performance (Westley \& Mintzberg, 1989). Moreover, CEOs have particular responsibilities for communicating corporate values to employees, by establishing an ethical climate, and providing a sense of purpose and direction (Pincus et al., 1991; Shockley-Zalabak, 2011).

The study identifies two CEO profiles from Italian large companies in terms of commitment in reputation management activities ("proactive" and "moderate" CEOs). These categories could be related with the leadership styles identified by some research (Blake \& Mouton, 1968; House, 1996). The style of proactive CEOs is in line with the participative leadership, in which leaders constantly interact with stakeholders, in order to build and improve company's reputation. Moderate CEOs seem to have some features of "Middle-of-the-Road", in which leaders try to achieve adequate goals in terms of interpersonal relations (Blake \& Mouton, 1968).

The findings related to RQ2 point out a possible relation between CEO tenure and CEO commitment in corporate reputation management. Long-tenured CEOs tend, in fact, to be more active in the main actions related to the management of firm's reputation (workplace, performance, innovation, citizenship, product and service, governance), compared to short-tenured CEOs. This supports the idea that longer CEO tenure reflects a greater sense of belonging and entrenchment to the organization, affecting the continuity of leadership (Ryan \& Wiggins, 2004) and facilitating the improvement of business performance (Song, 2006). Long-tenured CEOs seem, therefore, more likely to have acquired the right experiences and skills to successfully manage the relations with company's stakeholders.

The study reveals that, according to CEOs' view, CEOs reputation is increasingly intertwined with corporate reputation (RQ3). This confirms the strategic leadership perspective and the upper echelon theory, wherein a central underlying idea is that the firm is a reflection of its leaders (Hambrick \& Mason, 1984; Ireland \& Hitt, 2005) that have a pivotal role in setting and maintaining the organization's strategic course. CEOs are important catalysts for generating stakeholder's trust toward an organization. CEO, in fact, enacts the most visible leadership role (Westley \& Mintzberg, 1989) that determines the corporate culture and the formal policies of an organization (Dowling, 2001).

The findings of this study support also Kitchen and Laurence research (2005) showing that CEO reputation, in 
terms of its perceived impact on the corporate reputation, is most important in Italy. Indeed, in Italian context the role of CEO often coincides with that of founder (Handler, 1989; Ibrahim, 1992) that has a significant influence on the strategic management of the family organizations.

\section{Implications, Limitations and Future Research}

From a theoretical perspective, the study contributes to the ongoing debate on CEOs' role in organizational dynamics, providing first empirical evidence on the CEO commitment in corporate reputation management. In particular, it sheds light in the understanding the main activities that CEOs undertake to guarantee the building and the improvement of company's reputation. In fact, despite the growing attention of CEO behavior, there is a death of research in exploring the actions related to reputation management in which the CEO plays a key role.

The study also extends the knowledge on an important proxy of CEO reputation, that is the CEO tenure, investigating how this proxy can influence CEO engagement in corporate reputation issues, especially in the Italian context. Moreover, the study reinforces the value of the strategic leadership perspective, supporting the relation between CEO reputation and corporate reputation.

In addition to the theoretical implications, the paper also offers the managerial insights. The findings show that $\mathrm{CEO}$ commitment in corporate reputation can increase in relation to $\mathrm{CEO}$ tenure. It implies a reflection about the managerial skills and attitudes that CEOs must be provided during their tenure. Long-tenured CEOs should develop and improve abilities that contribute to create a positive reputation, such as motivational skills to strengthen a sense of belonging of employees to the organization; listening skills in order to meet consumers' needs and achieve good performance; open-mind vision to anticipate market's changes by introducing innovative choices; analytical acumen and familiarity with financial tools; ethical attitudes and communication competences. These skills allow CEO to maintain their position for a long time, and to obtain more contractual power than the other members of the dominant coalition (Bowen, 2009; Johansson \& Ottestig, 2011).

The study shows the link between CEO reputation and corporate reputation, confirming the potential of CEO's good name on the company' evaluations by stakeholders. The relationship between CEOs and corporate reputation is important to understand, given that corporate reputations are valuable intangible assets that are associated with a number of tangible benefits (Roberts \& Dowling, 2002; Love et al., 2017).

The halo effect of CEO reputation on the company can provide, in fact, important opportunities for a company (Carpenter, Geletkanycz, \& Sanders, 2004). In this regard, Gaines-Ross (2003) defines "CEO capital" as the strategic asset that enables to access to corporate resources, as the human and market capital, increasing the firm's competitive advantage (Ranft, Zinko, Ferris, \& Buckley, 2006). CEO reputation serves to reduce the uncertainty regarding expected future behavior of the leader (Baker \& Hall, 2004), and it is a key factor for long-term success and the survival of an organization (Fuller \& Jensen, 2010).

In this perspective, the influence of CEO reputation on corporate reputation stimulates $\mathrm{CEO}$, and corporate communication managers, to create an effective CEO brand, aligned with company's values (Ranft et al., 2006). CEO must be backed by the appropriate corporate communication specialists to develop programs for internal and external stakeholders in a manner consistent with the corporate identity (Kitchen \& Laurence, 2003).

Thus, CEO reputation represents a strategic resource that organizations can leverage for achieving competitive advantages, providing relevant clues to the firm's future direction and performance. However, it is important to consider that the strong link with CEO reputation could be risky for the organization' reputation, above all when CEOs undertake unethical behavior, or leave their office (Fry, 1997).

The study presents some limitations related to the circumscribed sample due to the difficulty in surveying CEOs directly, and the absence of qualitative analysis by which to understand more in-depth CEOs' view on reputation issues. Thus, this paper could guide future research on a larger sample, aimed to investigate further proxies of CEO reputation, such as CEO age, CEO insider or outsider.

Moreover, the paper is focused on the Italian context, characterized by some peculiarities, such as the prevalence of family businesses and the presence of long-tenured CEOs. Thus, this study can be viewed as a starting point for future cross-country comparison, in fact an extension of this research to other countries is required to determine if the same pattern holds true in different places.

\section{References}

Alsop, R. J. (2004). The 18 immutable laws of corporate reputation: Creating, protecting and repairing your most valuable asset. New York: Dow Jones \& Co.

AIDAF - Osservatorio AUB (Corbetta, G., Minichilli, A., \& Quarato, F.) (2014). Osservatorio AUB su tutte le 
aziende familiari italiane con ricavi superiori a 50 milioni di Euro. Retrieved from http://www.aidaf.it/wp-content/uploads/2014/08/5\%C2\%B0-Osservatorio-AUB_2013.pdf

Babbie, E. R. (2012). The basics of social research. Belmont, CA: Wadsworth publishing company.

Baik, B. O. K., Farber, D. B., \& Lee S. S. (2011). CEO ability and management earnings forecasts. Contemporary Accounting Research, 28(5), 1645-1668. https://doi.org/10.1111/j.1911-3846.2011.01091.x.

Baker, G. P., \& Hall, B. J. (2004). CEO incentives and firm size. Journal of Labor Economics, 22(4), 767-798. https://doi.org/10.1086/423154.

Balmer, J. M. T. (2001). Corporate identity, corporate branding ad corporate marketing. Seeing through the fog. European Journal of Marketing, 35(3/4), 248-291. https://doi.org/10.1108/03090560110694763

Bates, S. (2011). Discover your CEO brand: secrets to embracing and maximizing your unique value as a leader. New York, NY: McGraw Hill Professional.

Bernstein, R. S., Buse, K., \& Bilimoria, D. (2016). The Impact of CEO Tenure and Effective Board Performance on Organizational Change. American Journal of Management, 16(4), 26-38.

Blake, R. R. \& Mouton, J. S. (1968). The Managerial Grid; Key Orientations for Achieving Production through People. Houston, TX: Gulf Publishing.

Boling, J. R., Pieper, T. M., \& Covin, J. G. (2016). CEO tenure and entrepreneurial orientation within family and nonfamily firms. Entrepreneurship Theory and Practice, 40(4), 891-913. https://doi.org/10.1111/etap.12150.

Bowen, S. A. (2009). What communication professionals tell us regarding dominant coalition access and gaining membership. Journal of Applied Communication Research, 37(4), 418-443. https://doi.org/10.1080/00909880903233184

Brookman, J., \& Thistle, P. D. (2009). CEO Tenure, the Risk of Termination and Firm Value. Journal of Corporate Finance, 15, 331-344. http://dx.doi.org/10.1016/j.jcorpfin.2009.01.002

Brown, R., \& Sarma, N. (2007). CEO overconfidence, CEO dominance and corporate acquisitions. Journal of Economics and Business, 59(5), 358-379. https://doi.org/10.1016/j.jeconbus.2007.04.002

Burson-Marsteller (2003). Reputation management. CEO reputation. Retrieved from http://www.bm.com/expertise/rep_mgmt.html

Carter, S. M., \& Greer, C. R. (2013). Strategic leadership: Values, styles, and organizational performance. Journal of Leadership \& Organizational Studies, 20(4), 375-393. https://doi.org/10.1177/1548051812471724

Carpenter, M. A., Geletkanycz, M. A., \& Sanders, W. G. (2004). Upper echelons research revisited: Antecedents, elements, and consequences of top management team composition. Journal of Management, 30(6), 749-778. https://doi.org/10.1016/j.jm.2004.06.001

Carreras, E., Alloza, Á., \& Carreras, A. (2013). Corporate reputation. London: LID Editorial.

Chang, Y. Y., Sudipto, D., \& Gilles, H. (2010). CEO ability, pay, and firm performance. Management Science, 56(10), 1633-1652. https://doi.org/10.1287/mnsc. 1100.1205

Chung, K. H., Rogers, R. C., Lubatkin, M., \& Owers, J. E. (1987). Do insiders make better CEOs than outsiders. The Academy of Management Executive, 1(4), 325-331. https://doi.org/10.5465/ame.1987.4275652

Corbetta, G. (2010). Le aziende familiari. Strategie per il lungo periodo. Milano: Egea.

Daily, C. M., \& Johnson J. L. (1997). Sources of CEO power and firm financial performance: A longitudinal assessment. Journal of Management, 23(2), 97-117. https://doi.org/10.1177/014920639702300201

Dowling, G. R. (2001). Creating corporate reputations: Identity, image, and performance. New York, NY: Oxford University Press.

Economist Intelligence Unit (2005). Reputation: Risk of risks. Economist Intelligence Unit's Global Risk Briefing.

Feldman, R. (2004). Why Your CEO's Reputation Is Your Company's Message. The Public Relations Strategist, $10(3), 24-25$.

Ferris, G. R., Blass, F. R., Douglas, C., Kolodinsky, R. W., \& Treadway, D. C. (2003). Personal reputations in organizations. In Greenberg J. (Ed.). Organizational behavior: The state of the science (pp. 211-246), 
Mahwah, NJ: Lawrence Erlbaum Associates.

Finkelstein, S, Hambrick, D. C., Cannella, A. A. (2009). Strategic Leadership: Theory and Research on Eexecutives, Top Management Teams, and Boards. Oxford University Press: New York.

Fry, A. (1997). On one's best behavior. Marketing, 19, 25-27.

Fuller, J., \& Jensen, M. C. (2010). Just say no to Wall Street: Putting a stop to the earnings game. Journal of Applied Corporate Finance, 22(1), 59-63. https://doi.org/10.1111/j.1745-6622.2010.00261.x

Gaines-Ross, L. (2000). CEO Reputation: A Key Factor in Shareholder Value. Corporate Reputation Review, 3(4), 366-370. https://doi.org/10.1057/palgrave.crr.1540127

Gaines-Ross, L. (2003). CEO capital: A guide to building CEO reputation and company success. Hoboken, NJ: John Wiley \& Sons.

Gaines-Ross, L. (2008). Corporate Reputation: 12 Steps to Safeguarding and Recovering Reputation. New York, NY: John Wiley \& Sons.

Gardberg, N. A. (2017). Corporate Reputation: Fashion, Fad, or Phenomenon? Corporate Reputation Review, 20(3/4), 177-180. https://doi.org/10.1057/s41299-017-0033-4

Graffin, S. D., Wade, J. B., Porac, J. F., \& Mcnamee, R. C. (2008). The impact of CEO status diffusion on the economic outcomes of other senior managers. Organization Science, 19(3), 457-474. https://doi.org/10.1287/orsc.1080.0354

Gray, E. R., \& Balmer, J. M. T. (1998). Managing corporate image and corporate reputation. Long Range Planning, 31(5), 695-702. https://doi.org/10.1016/s0024-6301(98)00074-0

Hambrick, D. C. (2007). Upper Echelons Theory: An update. Academy of Management Review, 32(2), 2-10. https://doi.org/10.5465/amr.2007.24345254

Hambrick, D. C, \& Fukutomi, G. D. S. (1991). The seasons of a CEO's tenure. Academy of Management Review, 16(4): 719-742. https://doi.org/10.5465/amr.1991.4279621

Hambrick, D. C., Geletkanycz, M. A., \& Fredrickson, J. W. (1993). Top executive commitment to the status quo: Some tests of its determinants. Strategic Management Journal, 14(6), 401-418. https://doi.org/10.1002/smj.4250140602

Hambrick, D. C., \& Mason, P. (1984). Upper echelons: The organization as a reflection of its top managers. Academy of Management Review, 9(2), 193-206. https://doi.org/10.5465/amr.1984.4277628

Hamilton, J. T., \& Zeckhauser, R. (2004). Media coverage of CEOs: who? what? where? when? why?. Working paper, Stanford Institute of International Studies.

Handler, W. (1989). Methodological issues and considerations in studying family businesses. Family Business Review, 2(3), 257-276. https://doi.org/10.1111/j.1741-6248.1989.00257.x

Hatch, M. J., \& Schultz, M. (1997). Relations between organizational culture, identity and image. European Journal of marketing, 31(5/6), 356-365. https://doi.org/10.1108/03090569710167583

Hayward, M. L. A., \& Hambrick, D. C. (1997). Explaining premiums paid for large acquisitions: Evidence of CEO hubris. Administrative Science Quarterly, 42(1), 103-127. https://doi.org/10.2307/2393810

Hayward, M. L. A., Rindova, V. P., \& Pollock, T. G. (2004). Believing one's own press: The causes and consequences of CEO celebrity. Strategic Management Journal, 25(7), 637-653. https://doi.org/10.1002/smj.405

House, R. J. (1996). Path-goal theory of leadership: Lessons, legacy, and a reformulated theory. The Leadership Quarterly, 7(3), 323-352. https://doi.org/10.1016/s1048-9843(96)90024-7

Huang, S. (2013), “Zombie Boards: Board Tenure and Firm Performance”, Singapore Management University School of Accountancy. http://dx.doi.org/10.2139/ssrn.2302917

Ibrahim, A. B. (1992). Strategy formulation in small business: A conceptual framework. Journal of Small Business and Entrepreneurship, 9(4), 71-76. https://doi.org/10.1080/08276331.1992.10600415

Ireland, R. D., \& Hitt, M. A. (2005). Achieving and maintaining strategic competitiveness in the 21st century: The role of strategic leadership. Academy of Management Executive, 19(4), 63-77. https://doi.org/10.5465/ame.2005.19417908

Jensen, M., \& Zajac, E. J. (2004). Corporate elites and corporate strategy: How demographic preferences and 
structural position shape the scope of the firm. Strategic Management Journal, 25(6), 507-524. https://doi.org/10.1002/smj.393

Jian, G., Shi, X., \& Dalisay, F. (2014). Leader-Member Conversational Quality Scale Development and Validation Through Three Studies. Management Communication Quarterly, 28(3), 375-403. https://doi.org/10.1177/0893318914533201

Johansson, C., \& Ottestig, A. T. (2011). Communication executives in a changing world: Legitimacy beyond organizational borders. Journal of Communication Management, 15(2),144-164. https://doi.org/10.1108/13632541111126364.

Karuna, C. (2006). CEO reputation and the use of earnings-and stock-based performance measures in CEO evaluation. Working Paper, University of California at Irvine.

Karuna, C. (2009). CEO reputation and internal corporate governance. Working Paper, The Paul Merage School of Business.

Kitchen, P. J., \& Laurence, A. (2003). Corporate reputation: An eight-country analysis. Corporate Reputation Review, 6(2), 103-117. https://doi.org/10.1057/palgrave.crr.1540193

Kellermanns W., Eddleston K. A., Barnet T., \& Pearson A. (2008). An exploratory study of family member characteristics and involvement: Effects on entrepreneurial behavior in the family firm. Family Business Review, 21(1), 1-14. https://doi.org/10.1111/j.1741-6248.2007.00107.x

Kelly, L. M., Athanassiou, N. \& Crittenden, W. F. (2000). Founder centrality and strategic behavior in the family-owned firm. Entrepreneurship: Theory and Practice, 25(2), 27-42. https://doi.org/10.1177/104225870002500202

Lee, S. (2006). CEO reputation: who benefits-the firm or the CEO?. Working paper, University of Southern California.

Lo, F. Y., \& Fu, P. H. (2016). The interaction of chief executive officer and top management team on organization performance. Journal of Business Research, 69(6), 2182-2186. https://doi.org/10.1016/j.jbusres.2015.12.027

Love, E. G., Lim, J., \& Bednar, M. K. (2017). The face of the firm: The influence of CEOs on corporate reputation. Academy of Management Journal, 60(4), 1462-1481. https://doi.org/10.5465/amj.2014.0862

Luo, X., Kanuri, V. K., \& Andrews, M. (2014). How does CEO tenure matter? The mediating role of firmemployee and firm-customer relationships. Strategic Management Journal, 35(4), 492-511.

Malmendier, U., \& Tate, G. (2005). CEO overconfidence and corporate investment. The Journal of Finance, 60(6), 2661-2700. https://doi.org/10.1111/j.1540-6261.2005.00813.x

Melewar, T. C., \& Karaosmanoglu, E. (2006). Seven dimensions of corporate identity: A categorization from the practitioners' perspective. European Journal of Marketing, 40(7/8), 846-869. https://doi.org/10.1108/03090560610670025

Meng, J., \& Berger, B. K. (2013). What they say and what they do: Executives Affect Organizational Reputation through Effective Communication. In C. E. Carroll (Ed.). The Handbook of Communication and Corporate Reputation (pp. 306-317). Hoboken, NJ: Wiley.

Milbourn, T. T. (2003). CEO reputation and stock-based compensation. Journal of Financial Economics, 68(2), 233-262. https://doi.org/10.1016/s0304-405x(03)00066-7

Murray, K., \& White, J. (2005). CEOs' views on reputation management. Journal of Communication Management, 9(4), 348-358. https://doi.org/10.1108/13632540510621687

Naldi, L., Cennamo, C., Corbetta, G., \& Gomez-Mejia, L. (2013). Preserving socio-emotional wealth in family firms: Asset or liability? The moderating role of business context. Entrepreneurship Theory and Practice, 37(6),1341-1360. https://doi.org/10.1111/etap.12069

Park, D.J., \& Berger, B. K. (2004). The presentation of CEOs in the Press, 1990-2000: Increasing salience, positive valence, and a focus on competency and personal dimensions of image. Journal of Public Relations Research, 16(1), 93-125. https://doi.org/10.1207/s1532754xjprr1601_4.

Parrino, R. (1997). CEO turnover and outside succession a cross-sectional analysis. Journal of financial Economics, 46(2), 165-197. https://doi.org/10.1016/s0304-405x(97)00028-7.

Pincus, J. D., Robert, A. P., Rayfield, A. P., \& Debonis, J. P. (1991). Transforming CEOs into Chief 
Communication Officers. Public Relations $22-27$. https://doi.org/10.1207/s1532754xjprr0301-4_1.

Ranft, A. L., Zinko, R., Ferris, G. R., \& Buckley, M. R. (2006). Marketing the image of management: The costs and benefits of CEO reputation. Organizational Dynamics, 35(3), 279-290. https://doi.org/10.1016/j.orgdyn.2006.05.003

Reputation Institute. (2012). Navigating the Reputation Economy: A Global Survey of Corporate Reputation Officers. Retrieved

from http://reputationmatters.me/wp-content/uploads/2012/12/2012_CRO_Global_Whitepaper.pdf

Reputation Institute. (2017). Global RepTrak 100. The World's Most Reputable Companies. Retrieved from http://www.ideeideas.it/press/global_reptrak_2017.pdf

Rindova, V. P., Williamson, I. O., Petkova, A. P., \& Sever, J. M. (2005). Being good or being known: An empirical examination of the dimensions, antecedents, and consequences of organizational reputation. Academy of Management Journal, 48(6),1033-1049. https://doi.org/10.5465/amj.2005.19573108

Roberts, P. W., \& Dowling, G. R. (2002). Corporate reputation and sustained superior financial performance. Strategic management journal, 23(12), 1077-1093. https://doi.org/10.1002/smj.274

Rose, C., \& Thomsen, S. (2004). The Impact of Corporate Reputation on Performance: Some Danish Evidence. European Management Journal, 22(2), 201-210. https://doi.org/10.1016/j.emj.2004.01.012

Ryan, H. \& Wiggins, R. (2004). Who is in Whose Pocket? Director Compensation, Board Independence, and Barriers to Effective Monitoring. Journal of Financial Economics, 73(3), 497-524. https://doi.org/10.1016/j.jfineco.2003.11.002

Serfling, M. A. (2014). CEO age and the riskiness of corporate policies. Journal of Corporate Finance, 25 , 251-273. https://doi.org/10.1016/j.jcorpfin.2013.12.013

Shane, S., \& Cable, D. (2002). Network Ties, Reputation, and the Financing of New Ventures. Management Science, 48(3), 364-381. https://doi.org/10.1287/mnsc.48.3.364.7731

Shen, W., \& Cannella, A. A. (2002). Revisiting the performance consequences of CEO succession: The impacts of successor type, post-succession senior executive turnover, and departing CEO tenure. Academy of Management Journal, 45(4), 717-733. https://doi.org/10.2307/3069306

Shi, W., Zhang, Y., \& Hoskisson, R. E. (2017). Ripple effects of CEO awards: Investigating the acquisition activities of superstar CEOs' competitors. Strategic Management Journal, 28(10), 2080-2102. https://doi.org/10.1002/smj.2638

Shockley-Zalabak, P. (2011). Fundamentals of organizational communication. Toronto: Pearson Education.

Sohn, Y., Lariscy, R. W., \& Tinkham, S. F. (2009). The impact of CEO reputation: Negative news and economic decisions. International Journal of Strategic Communication, 3(1), 1-18. https://doi.org/10.1080/15531180802606596

Song, F. (2006). CEO longevity and corporate performance: theory and evidence on the bright and dark sides of leadership continuity. Job Marketing Paper, 18 November, Retrieved from http://bschool.nus.edu/Departments/FinanceNAccounting/Seminars/2007seminars/FenghuaSong-050207/Fe nghuaSong-050207-JMP.pdf

Van Der Jagt, R. (2005). Senior Business Executives See Communication and Reputation as a Crucial Part of Their Leadership Role. Corporate Reputation Review, 8(3), $179 \quad 186$. https://doi.org/10.1057/palgrave.crr.1540248

Vera, D., \& Crossan, M. (2004). Strategic leadership and organizational learning. Academy of management review, 29(2), 222-240. https://doi.org/10.5465/amr.2004.12736080

Waldman, D. A., Siegel, D. S., \& Javidan M. (2006). Components of CEO Transformational Leadership and Corporate Social Responsibility. Journal of Management Studies, 43(8), 1703-1725. https://doi.org/10.1111/j.1467-6486.2006.00642.x

Watson, T. (2007). Reputation and ethical behaviour in a crisis: predicting survival. Journal of Communication Management, 11(4), 371-384. https://doi.org/10.1108/13632540710843959

Weigelt, K., \& Camerer, C. (1988). Reputation and corporate strategy: A review of recent theory and applications. Strategic management journal, 9(5), 443-454. https://doi.org/10.1002/smj.4250090505 
Weisbach, M. (1988). Outside Directors and CEO Turnover. Journal of Financial Economics, 20(1/2), 431-460. https://doi.org/10.1016/0304-405x(88)90053-0

Weng, P. S., \& Chen, W. Y. (2017). Doing good or choosing well? Corporate reputation, CEO reputation, and corporate financial performance. The North American Journal of Economics and Finance, 39, 223-240. https://doi.org/10.1016/j.najef.2016.10.008

Westley, F., \& Mintzberg, H. (1989). Visionary leadership and strategic management. Strategic Management Journal, 1(1), 17-32. https://doi.org/10.1002/smj.4250100704

Wulf, T., Stubner, S., Miksche, J. and Roleder, K. (2010), "Performance over the CEO Lifecycle - A Differentiated Analysis of Short and Long Tenured CEOs", HHL - Leipzig Graduate School of Management, $\quad$ working $\quad$ Paper $\quad$ No. 88 Retrieved from: http://www.hhl.de/fileadmin/texte/publikationen/arbeitspapiere/hhlap0088.pdf

Yim, S. (2013). The acquisitiveness of youth: CEO age and acquisition behavior. Journal of financial economics, 108(1), 250-273. https://doi.org/10.1016/j.jfineco.2012.11.003

Yucel, I., McMillan, A., \& Richard, O. C. (2014). Does CEO transformational leadership influence top executive normative commitment? Journal of Business Research, 67(6), 1170-1177. https://doi.org/10.1016/j.jbusres.2013.05.005

Zhang, Y., \& Rajagopalan, N. (2010). Once an outsider, always an outsider? CEO origin, strategic change, and firm performance. Strategic Management Journal, 31(3), 334-346. https://doi.org/10.1002/smj.812

\section{Copyrights}

Copyright for this article is retained by the author(s), with first publication rights granted to the journal.

This is an open-access article distributed under the terms and conditions of the Creative Commons Attribution license (http://creativecommons.org/licenses/by/4.0/). 